Perhaps, therefore, the following facts will be of interest.

(a) In a work entitled " Knowledge Acquired concerning the Production of Gold," an edition of the text of which, with a translation, I have in the press (Geuthner, Paris), the author, Abu'l-Qāsim Muhammad ibn Ahmad al-'Irāqī, quotes several passages which he attributes to Marianus (Morienus, supra), the teacher of Khālid ibn Yazīd. Many of these passages occur in the Latin "Liber de Compositione Alchemiae," ascribed to Morienus, which is to be found on pp. 509-5I9 of vol. i. of Mangeta's "Bibliotheca Chemica Curiosa" (I 702).

(b) On p. $2 \mathrm{I} 7$ of vol. ii. of the latter treatise is a work entitled "Epistola Solis ad Lunam crescentem," which begins, "In tenuitate enim nimia dabo tibi de pulchritudine mea lumen." This work is strongly Arabic in atmosphere, and is apparently a translation of the "Risālatu'l-shams ila al-hilāl" (Letter of the Sun to the New Moon) written by Abu 'Abdullah Mubammad ibn Umail at-Tamimi, who lived in the second half of the third century after the Flight (ca. A.D. 900). There is a manuscript of this work, with a commentary by Al-Jildaki, in the British Museum ( $A d d .23,418$, xvi.). The Latin line quoted above is an exact translation of the first line of the Arabic poem; I have not yet seen the MS., so that I cannot say whether the agreement between the " Epistola" and the " Risāla" holds throughout.

The second part of Berthelot's statement, namely, that in which he expresses his opinion that Geber's works are forgeries, opens a question too wide for discussion here. I would point out, however, that Berthelot examined less than a dozen of the Arabic works of Jābir ibn Haiyān, and as the latter is said to have written more than 500 books Berthelot was perhaps a little premature. Jābir, in his "Book of Properties " (a manuscript of which is preserved in the British Museum), refers to another book of his called "The Summary," which may possibly be the "Summa" of Geber. There is, moreover, in Mangeta (vol. i. p. 562) a work entitled "Testamentum Gebri"; now a commentator of Jãbir's "Book of Mercy" refers to the same author's " Kitāb wasiyya mautihi," or "The Book of his Last Will and Testament."

Evidence of this and other sorts is gradually accumulating, and it would not surprise me to find that Geber and $A b \bar{u}$ Mūsā Jābir ibn Haiyān were, as for so many centuries they were held to be, one and the same.

Clifton College, October 9.

\section{On the Occurrence of the Archiannelids, Saccocirrus and Protodrilus, on the South and West Goasts of England.}

IN NAtURE (vol. 9I, pp. 85 and 348 ) the present writer recorded in 1913 the occurrence-for the first time in England-of abundance of Protodrilus in many situations, and a few Saccocirrus in one situation near Plymouth, and it was shown that both these forms have the curious preference for situations near high-water mark where fresh water trickles through or over the foreshore at low water, but covered by sea water at high tide (l.c. 348). Since I9r3 the writer has searched for and found Protodrilus in similar situations and in a large number of places between Salcombe and Falmouth, and this year was successful in taking the same animal at two places on the west coast of England, namely, on September 7, near high-water mark where the Wanson (so-called) river runs into the sea at the south end of Widemouth
Bay near Bude. (See Ord. Survey Map, I in. to mile, river Torridge, Sheet I27, IH, 47-53), and on September 22 in a similar situation on a beachformerly well known for shells-at Woolacombe (see O.S. Map, I in. to mile, Barnstaple, Sheet II9, $\left.{ }_{4} \mathrm{C}, \mathrm{I} 6-02\right)$.

In $\mathrm{I} 9 \mathrm{I} 7$ and on various occasions since, the writer has also taken large numbers of Saccocirrus (e.g., 8o from a hole in the gravel about I $\mathrm{ft}$. by $\mathrm{I} \mathrm{ft}$. deep in half an hour) on a beach at Portwrinkle in Whitsand Bay (see Ord. Sur. Map, I in. to mile, Plymouth, Sheet $I_{4} 8,{ }_{5} F$, $\left.83-I_{5}\right)$ in a position exactly similar to that described formerly (l.c. p. 348). This year a few individuals were also taken in the gravel on the above-mentioned shell-beach at Woolacombe. Protodrilus and Saccocirrus therefore probably occur in all suitable situations in the south-west of England, and may no doubt be recorded-after search in suitable places-from a much more extended area in the British Isles. The specimens of each genus from all localities belong respectively to one species, so far as can be gathered from external characters, namely Protodrilus flavocapitatus, and an apparently new and as yet undescribed species of Saccocirrus. It is hoped that the characteristic restless side-to-side movement of the head and anterior region of Saccocirrus may shortly be portrayed by cinematograph.

Living in about the same situation as Protodrilus and Saccocirrus is almost always found the planarian Gunda ulvae. This planarian is large and easily found under stones in pools, and therefore serves as a guide in the search for the archiannelids. The apparent positive geotropism of Gunda, which is probably true, is an interesting phenomenon and not well known; if a number of the planarians be taken on a flat stone, they can be made to change direction a large number of times by holding the stone vertically towards the light and turning it repeatedly through an angle of $180^{\circ}$.

The occurrence of the above-mentioned animals only in the peculiar habitat where the water undergoes violent fluctuations in salinity suggests the presence of an undetected special food supply.

\section{Marine Biological Laboratory, The Hoe, Plymouth, October ro.}

\section{Origin of the Name of the Genus Masaris.}

In Ed. André, " Species des Hyménoptères d'Europe et d'Algérie," vol. ii. p. 829 , it is stated that the derivation of the name "Masaris" is unknown. The first species described under this genus is $M$. vespiformis F., from Egypt; it also occurs in Algeria.

May I suggest that the origin of the name is the Arabic name for Egypt, "Masr" (also used colloquially for its capital, Cairo). As a common noun "masr" means " a fortified place," and its plural is "amsar"; the word is connected with the Hebrew word rendered "Mizraim " in Genesis. It has long seemed to me that this derivation is at least probable, and I should be glad to know if any other has been suggested.

Turf Club, Cairo, September 26.

FABRICIUS, I793, “ Ent. Syst." ii. p. 283, in founding the genus Masaris, did not indicate any derivation for the name, and L. Agassiz, I 845, "Nomencl. Zool. (Hymenoptera)," masks his inability to give a derivation by the suggestion that Masaris is a proper name. 